\title{
Physical, chemical and mechanical properties of Pinus sylvestris wood at five sites in Portugal
}

\author{
Cláudia Fernandes ${ }^{(1)}$ \\ Maria João Gaspar ${ }^{(1-2-3)}$, \\ Jani Pires ${ }^{(2)}$, \\ Ana Alves ${ }^{(3)}$, \\ Rita Simões ${ }^{(3)}$, \\ José Carlos Rodrigues ${ }^{(3)}$, \\ Maria Emília Silva ${ }^{(4-5)}$, \\ Ana Carvalho ${ }^{(1)}$, \\ José Eduardo Brito ${ }^{(1-2)}$, \\ José Luís Lousada ${ }^{(4-5)}$
}

\begin{abstract}
The reduction of resinous species in Portuguese forest areas has caused constraints to wood industry supplies. Portugal represents the extreme southwest of Scots pine (Pinus sylvestris) natural distribution and large gaps exist in the knowledge of its wood-quality characteristics. Understanding the relationship between these traits is important for recognizing which combination of wood properties is the most suitable for specific uses. To address these questions, we assessed wood-quality traits, namely, wood-density components (microdensitometric analysis), chemical composition (NIR spectrometry) and mechanical properties (bending tests) of wood samples collected at five representative forest sites in Portugal. Our results showed that Portuguese Pinus sylvestris has good radial growth and denser wood, higher extractive content and higher stiffness and strength than northern European provenances. The lignin content was within the range attributed to softwoods. Among the Portuguese stands, trees growing at lower-altitude sites exhibited denser wood and higher mechanical properties, while trees from high-elevations showed higher amounts of lignin. Ring density was more strongly correlated with earlywood than latewood density. A negative, non-significant correlation was found between ring density and width, supporting the assumption that the higher radial growth (ring width) does not negatively affect wood quality (density). In general, chemical properties had a weak relationship with physical and mechanical properties (MOE and MOR). Both mechanical traits were positively correlated with density and growth components, supporting the assumption that trees with high radial growth do not exhibit poorer mechanical performances.
\end{abstract}

Keywords: Bending Tests, Correlations, Mechanical Traits, NIR Spectrometry, Scots Pine, Wood-Density Components, Wood Quality, X-ray Microdensitometry high variability of its timber in terms of density, strength, extractive content and wood appearance (Verkasalo \& Leban 2002, Peltola et al. 2009, Auty et al. 2014).

Portugal represents the outermost western limit of Scots pine's natural range; however, large gaps in the knowledge of its wood characteristics exist in the country. Moreover, in recent years the reduc-
(1) BiolSI - Biosystems \& Integrative Sciences Institute, Faculty of Sciences University of Lisboa, C8 BDG Campo Grande (Portugal); (2) Department of Genetics and Biotechnology (DGB), University of Tras-os-Montes and Alto Douro, 5001-801 Vila Real (Portugal); (3) Centro de Estudos Florestais (CEF), Instituto Superior de Agronomia, Universidade de Lisboa, Tapada da Ajuda, 1349-017 Lisboa (Portugal); (4) Department of Forestry Sciences and Landscape (CIFAP), University of Tras-os-Montes and Alto Douro, 5001-801 Vila Real (Portugal); (5) Centre for the Research and Technology of Agro-Environmental and Biological Sciences (CITAB), University of Tras-os-Montes and Alto Douro, 5001-801 Vila Real (Portugal)

@ José Luís Lousada (jlousada@utad.pt)

Received: Oct 18, 2016 - Accepted: Mar 28, 2017

Citation: Fernandes C, Gaspar MJ, Pires J, Alves A, Simões R, Rodrigues JC, Silva ME, Carvalho A, Brito JE, Lousada JL (2017). Physical, chemical and mechanical properties of Pinus sylvestris wood at five sites in Portugal. iForest 10: 669-679. - doi: 10.3832/ifor2254010 [online 2017-07-11]

Communicated by: Giacomo Gol tion of resinous species in Portuguese forested areas has caused strong constraints to wood industry supplies. In this scenario, to meet timber demand a future increase of Scots pine stands in Portugal through reforestation of mountain regions is desirable, especially at the higher elevations, where other species such as Pinus pinaster show reduced vigor and profitability, and where the risk of pinewood nematode (Bursaphelenchus xylophilus Nickle) attacks is weaker.

Wood is a complex biological material whose characteristics depend on various internal and external factors, and consists of sets of flexible pipes of cellulose and hemicellulose connected and made stiff by lignin (Pereira et al. 2003). However, wood is highly variable and anisotropic (i.e., its properties vary depending on direction) as the result of unequal cambial growth and orientation of wood fibres. Understanding such variability is of critical importance to improve the quality, processing and use of wood (Zobel \& Van Buijtenen 1989, Koga \& Zhang 2004). In particular, wood quality is defined as the specific combination of its properties that are most suitable for a specific final product (Zobel \& Van Buijtenen 1989), and depends on physical (e.g., wood density), chemical (composition and con- 
Fig. 1 - Location of the sampled sites.

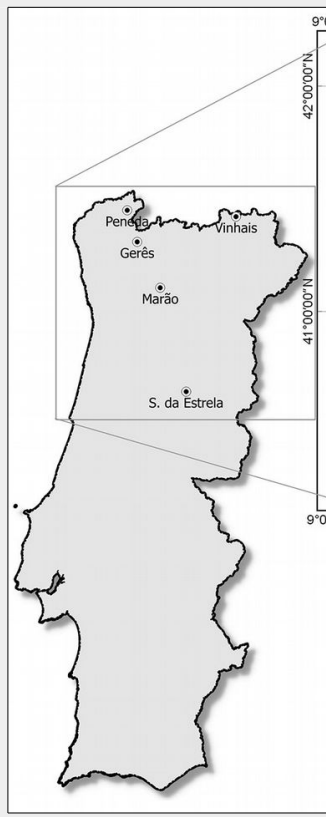

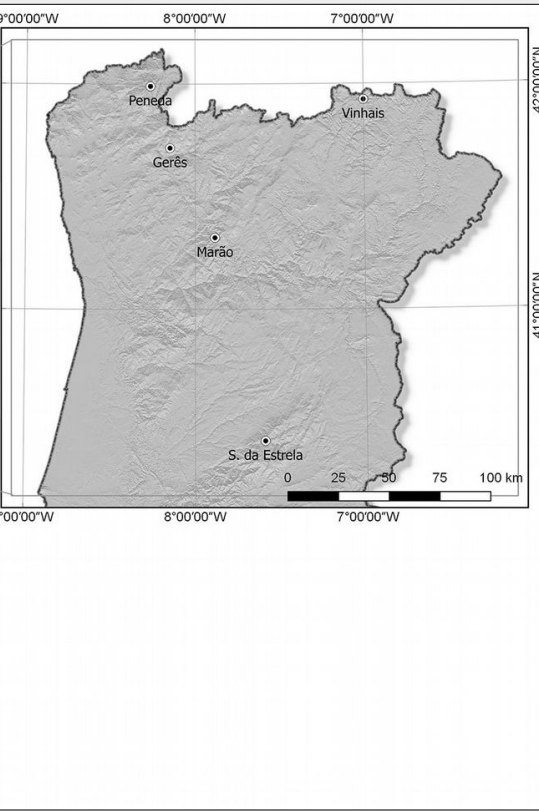

tent of cellulose, hemicellulose and lignin), anatomical (morphology of the wood cell), and mechanical (modulus of elasticity and rupture) features of wood (Zobel \& Van Buijtenen 1989, Steffenrem et al. 2007). and mechanical strength (Verkasalo \& Leban 2002), retractility (Riesco-Muñoz et al. 2008), resistance to biodegradation (ReyPrieto \& Riesco-Muñoz 2012), and the derived paper quality (Sable et al. 2012) are strongly affected by intrinsic wood properties such as density (mass of wood cell wall material per unit volume), which is considered one of the most important indicator of wood quality (Zobel \& Van Buijtenen 1989), along with fibre and microfibril orientation. However, wood density can vary both within and among trees as a result of the combinations of various density components (Gaspar et al. 2008a). In this respect, $x$-ray wood microdensity analysis can provide important information on the physiological process underlying wood formation, allowing the cambial activity to be analysed along the growing season in response to different environmental effects (Zobel \& Van Buijtenen 1989).
Many wood properties such as stiffness

Chemical composition of cell-wall components has been proven to influence several wood properties and therefore the suitability of wood to specific purposes (Pereira et al. 2003). In particular, the high resistance of wood to axial deformation is thought to be due to cellulose (Tsoumis 1991). Lignin serves as an aggregator agent between the cellulose microfibrils and adjacent cells of the cell walls, conferring to wood rigidity and resilience to impact and compression. Lignin also plays a protective role against external pathogens in trees and enhances the hydrophobicity of plant cell walls for water conduction (Pereira et al. 2003). The most widely used method for determining lignin content is the Klason method, which consists of the hydrolysis of polysaccharides. However, near infrared spectroscopy (NIRS) is a simple, rapid and highly reproducible method which has recently relieved wet-chemistry techniques for the determination of the chemical composition of lignocellulosic materials (Schimleck et al. 2003).

Wood extractives are organic and inorganic non-structural components of the cell wall which contribute to color, smell,

Tab. 1 - Geographical, climatic and stand characteristics of the 5 study sites.

\begin{tabular}{lccccc}
\hline Characteristics & Marão & Vinhais & Peneda & Gerês & $\begin{array}{c}\text { S. da } \\
\text { Estrela }\end{array}$ \\
\hline Sampled trees & 20 & 20 & 20 & 20 & 20 \\
\hline Latitude (N) & $41^{\circ} 19^{\prime} 03^{\prime \prime}$ & $41^{\circ} 55^{\prime} 44^{\prime \prime}$ & $41^{\circ} 59^{\prime} 23^{\prime \prime}$ & $41^{\circ} 42^{\prime} 56^{\prime \prime}$ & $40^{\circ} 24^{\prime} 54^{\prime \prime}$ \\
\hline Longitude (W) & $0^{\circ} 53^{\prime} 03^{\prime \prime}$ & $07^{\circ} 00^{\prime} 03^{\prime \prime}$ & $08^{\circ} 15^{\prime} 54^{\prime \prime}$ & $08^{\circ} 08^{\prime} 56^{\prime \prime}$ & $07^{\circ} 35^{\prime} 33^{\prime \prime}$ \\
\hline Altitude (m a.s.l.) & 935 & 1128 & 1105 & 815 & 1424 \\
\hline Average age (years) & 49 & 51 & 52 & 66 & 46 \\
\hline Mean annual rainfall $(\mathrm{mm})$ & 1131 & 855 & 1195 & 1205 & 1125 \\
\hline Mean annual temperature $\left({ }^{\circ} \mathrm{C}\right)$ & 14.0 & 11.6 & 14.9 & 14.4 & 13.5 \\
\hline Köpen-Geiger climate & $\mathrm{Csb}$ & $\mathrm{Csb}$ & $\mathrm{Csb}$ & $\mathrm{Csb}$ & $\mathrm{Csb}$ \\
classification & 460 & 500 & 380 & 400 & 460 \\
\hline Stand density (trees ha-1 $)$ & 18.3 & 16.7 & 17.2 & 16.5 & 16.5 \\
\hline Mean tree height $(\mathrm{m})$ & 29.2 & 27.2 & 34.6 & 33.0 & 27.4 \\
\hline Mean diameter at $1.3 \mathrm{~m}(\mathrm{~cm})$ & & & & & \\
\hline
\end{tabular}

decay resistance, flammability, and density and can be removed by solvent extraction. In some species, these compounds provide resistance to decay and insect attack and sometimes affect the specific gravity, thus indirectly changing wood physical properties (Rey-Prieto \& Riesco-Muñoz 2012).

Due to its simplicity, the bending test is commonly used to assess the mechanical properties of wood compounds. The measure of wood stiffness when loaded by bending is expressed by the modulus of elasticity (MOE), while the maximal load capacity in bending is expressed by the modulus of rupture (MOR - Verkasalo \& Leban 2002, Auty 2006). For P. sylvestris, MOE ranges from 11.6 to $13 \mathrm{Gpa}$ and MOR from 64.2 to $85.6 \mathrm{MPa}$ (Verkasalo \& Leban 2002, Hoibo \& Vestol 2010).

Understanding the relationship between physical, anatomical, chemical and mechanical properties of wood is important to determine which combination of its properties is the most suitable for a specific final product. Phenotypic correlations between traits may be inherent (i.e., having a genetic basis), a response to the environmental conditions (i.e., due to acclimation), or a combination of both (Abdel-Gadir et al. 1993).

The aim of this study was: (i) to evaluate wood-quality traits (physical, chemical, and mechanical) of Pinus sylvestris growing in Portugal, and compare the results with other European provenances of the same species, as well as with other species; and (ii) to evaluate the relationship (correlations) between wood-quality traits in Portuguese Scots pine.

\section{Materials and methods}

In this study, we determined the wooddensity components by microdensitometric analysis, chemical composition (in terms of macromolecules) using the NIR spectrometric method, and mechanical properties using three-point bending tests (radial modulus of elasticity $-\mathrm{MOE}_{\mathrm{rad}}$, and radial modulus of rupture $-M O R_{r a d}$ ). The analysis was conducted on 100 adult Pinus sylvestris trees from five representative sites in Portugal.

\section{Plant material}

Five sampling sites were selected as representative of the whole range of Pinus sylvestris in Portugal (Fig. 1). The location, number of sampled specimens, and the main characteristics of the selected stands are reported in Tab. 1. At each site, 20 adult trees were randomly sampled, totaling 100 individuals. Trees that were isolated or at the border, bifurcated, not dominant, or having an apparent deficient sanitary condition were excluded from sampling.

Wood samples were collected at breast height $(1.3 \mathrm{~m})$ by extraction of one increment core of $12 \mathrm{~mm}$ per tree, from barkpith-bark, following the direction of the lowest pith eccentricity and as perpendicular as possible to the tree axis. 
Fig. 2 - Microdensitometer and $\mathrm{x}$ ray apparatus. An example of the data obtained by microdensitometric analysis is displayed in the bottom panel.
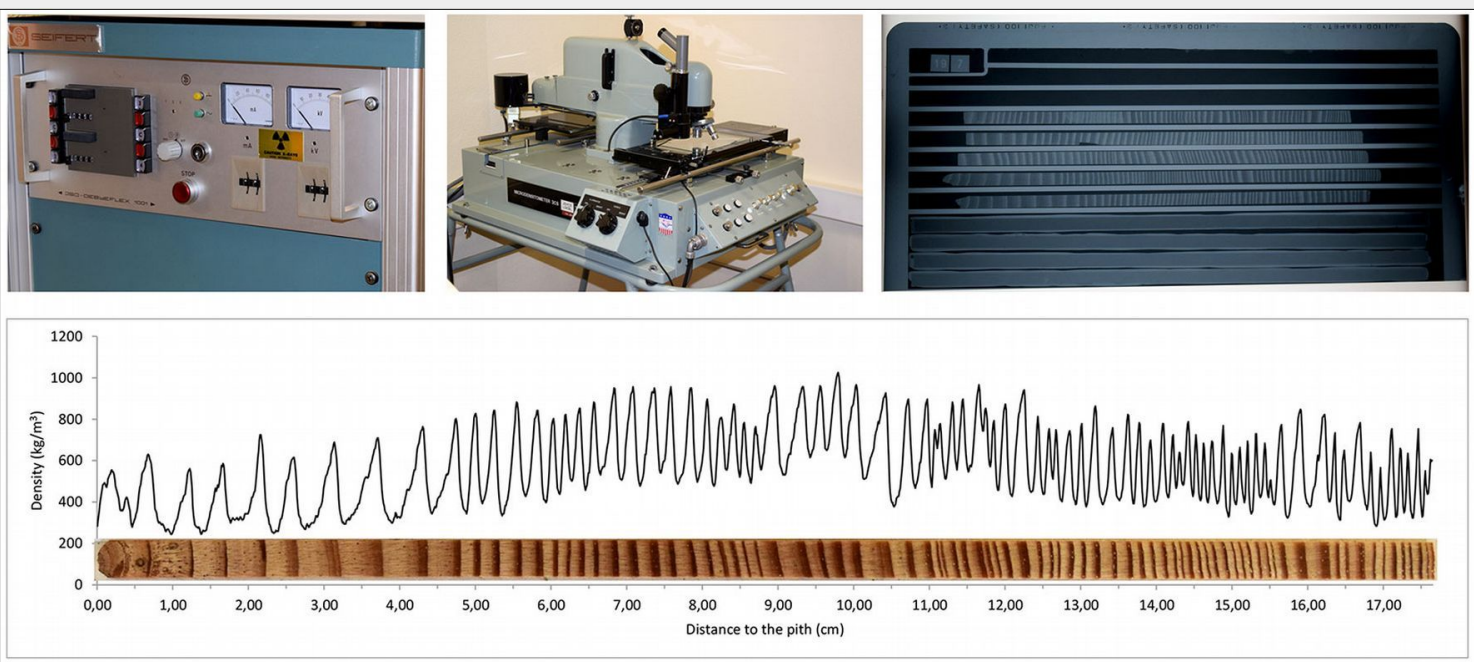

\section{Microdensitometric analysis}

From the increment cores, 2-mm radial strip segments (from pith to cambium) were prepared. These strips were air-dried and conditioned to $12 \%$ moisture content. The radial samples were $\mathrm{x}$-rayed perpendicularly to the transverse section, and their image was scanned by microdensitometric analysis (Louzada 2000). The time of exposure to radiation was $300 \mathrm{~s}$, at an intensity of $18 \mathrm{~mA}$ and an accelerating tension of 12 $\mathrm{kV}$, and the distance between the $\mathrm{x}$-ray source and the film was $2.5 \mathrm{~m}$. The data comprising radial density profiles were recorded every $100 \mu \mathrm{m}$ with a slit height (tangential direction) of $455 \mu \mathrm{m}$. Along with the wood samples, standards of cellulose acetate of known thicknesses and real densities were also $x$-rayed. Because their $x$-ray affinity is similar to that of the wood, the conversion of optical density to real density could be obtained by linear regression. Through this process, it is possible to determine wood density in a step of $100 \mu \mathrm{m}$ from pith to bark, which provides a continuous radial density record throughout the tree's life (Fig. 2).

Using these data, several density components for each growth ring were determined: average ring density (RD), earlywood density (EWD), latewood density (LWD) and heterogeneity index (HI). In addition, other components related to tree growth were measured: latewood percentage (LWP), earlywood width (EWW), latewood width (LWW) and ring width (RW).

The growth ring boundaries on the radial profiles were identified by locating sharp density variations with cross-examination through visual observation of the macroscopic anatomical features. The earlywoodlatewood boundary in each growth ring was determined by the average of the minimum and maximum density values within each ring (Rozenberg et al. 2001). To determine the $\mathrm{HI}$, we used the method proposed by Ferrand (1982, cited in Louzada \& Fonseca 2002), which express the heterogeneity based on the standard deviation of all individual density values in each ring.

\section{Near infrared spectroscopy}

The material left from each increment core after removing the radial strip for $x$ ray analysis was preliminarily milled in a Retsch SM 100 cutting mill with a 6-mm sieve and further milled with a Retsch Ultra Centrifugal Mill ZM 100 with a 1-mm screen sieve. Aliquots of the milled wood were then Soxhlet-extracted with dichloromethane, ethanol, and water. The Fourier-transformed near infrared (FT-NIR) spectra were obtained in the wave number range of 12,000 to $3,800 \mathrm{~cm}^{-1}$ using a Bruker MPA spectrometer (Bruker Optics, Ettlingen, Germany) in diffuse reflectance mode with a spinning cup module. Each spectrum was obtained with 100 scans at spectral resolution of $8 \mathrm{~cm}^{-1}$, and zero filling of two was applied.

The Klason lignin content (based on extractive free oven-dry weight) and composition $(\mathrm{H} / \mathrm{G}$ based on extractive free material) were estimated by NIR-based PLS-R models using the OPUS-Quant software (Bruker Optics, Ettlingen, Germany). The models had a prediction error of $0.26 /$ 0.35 (RMSEC/RMSECV) and $0.002 / 0.002$ (RMSEC/RMSECV) for Klason lignin content and composition $(\mathrm{H} / \mathrm{G})$, respectively (unpublished data). The predictions of these models are more accurate than those of the PLS-R models previously reported for Pinus pinaster (Alves et al. 2006, Da Silva Perez et al. 2007, Gaspar et al. 2011) and similar to those of the models for Picea abies (Schwanninger et al. 2011a, 2011b).

\section{Radial mechanical properties}

For this analysis, the same strips from the microdensitometric analysis were used. $\mathrm{MOE}_{\mathrm{Rad}}$ (modulus of elasticity in radial direction) and $M O R_{\text {Rad }}$ (modulus of rupture in radial direction) were evaluated through three-point bending tests (Gaspar et al. 2011). Before testing, the specimen dimensions (thickness and width) were measured with a digital calliper (0.01 $\mathrm{mm}$ resolution). Bending tests were carried out at room temperature by using an electro-mechanical testing machine (Instron 5848 Micro-
Tester ${ }^{\oplus}$ ) with a $0.5 \mathrm{~mm} \mathrm{~min}^{-1}$ displacement control and 40-mm span (Fig. 3).

\section{Data analysis}

The means of measured variables at each site were compared by the Duncan's multiple range mean comparison test $(p<0.05)$, and pairwise Pearson's correlation coefficients among all traits were estimated. All the statistical analyses were performed using JMP statistical software (SAS Institute Inc.).

\section{Results and discussion}

\section{Mean values of wood-quality traits}

The mean values of wood-density components, and chemical and mechanical properties at each site are summarized in Tab. 2 and Tab. 3, respectively. The results of this study and previous findings from other studies and regions were compiled in Tab. 4 and Tab. 5 to facilitate their comparison and the discussion of results. Tab. 4 contains data concerning density components.

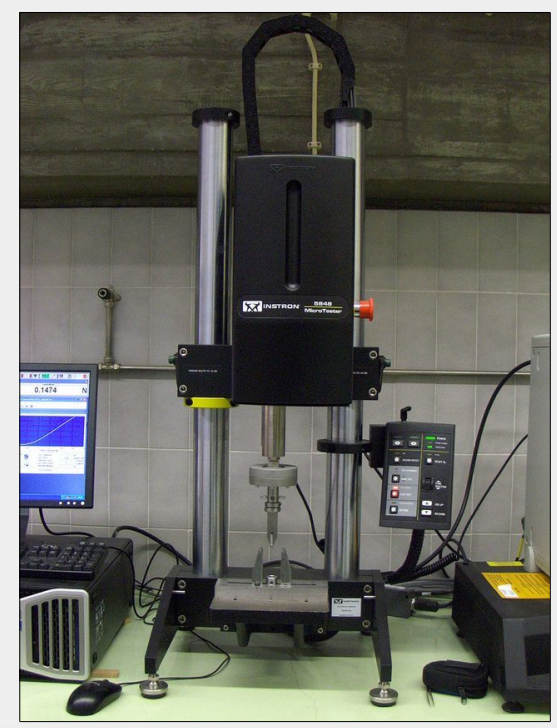

Fig. 3 - The Instron 5848 MicroTester machine used for the bending tests. 
Tab. 2 - Mean values ( \pm standard deviation) and results of the comparison test for wood-density components. (RD): average ring density ( $\left.\mathrm{kg} \mathrm{m}^{-3}\right)$; (EWD): earlywood density $\left(\mathrm{kg} \mathrm{m}^{-3}\right)$; (LWD): latewood density $\left(\mathrm{kg} \mathrm{m}^{-3}\right)$; (LWP): latewood percentage (\%); (EWW): earlywood width (mm); (LWW): latewood width (mm); (RW): ring width ( $\mathrm{mm})$; (HI): heterogeneity index (kg $\left.\mathrm{m}^{-3}\right)$. Different letters in the same column indicate significant differences $(p<0.05)$ between sites after Duncan's multiple range test.

\begin{tabular}{lcccccccc}
\hline Site & RD & EWD & LWD & LWP & EWW & LWW & RW & HI \\
\hline Marão & $548 \pm 0.061^{\mathrm{b}}$ & $405 \pm 0.054^{\mathrm{a}}$ & $841 \pm 0.073^{\mathrm{c}}$ & $33.26 \pm 4.68^{\mathrm{a}}$ & $2.52 \pm 0.59^{\mathrm{b}}$ & $1.21 \pm 0.37^{\mathrm{b}}$ & $3.72 \pm 0.87^{\mathrm{b}}$ & $219 \pm 0.026^{\mathrm{c}}$ \\
Vinhais & $544 \pm 0.063^{\mathrm{b}}$ & $421 \pm 0.059^{\mathrm{a}}$ & $774 \pm 0.067^{\mathrm{b}}$ & $35.20 \pm 4.45^{\mathrm{ab}}$ & $1.85 \pm 0.33^{\mathrm{a}}$ & $1.00 \pm 0.24^{\mathrm{a}}$ & $2.86 \pm 0.49^{\mathrm{a}}$ & $183 \pm 0.031^{\mathrm{b}}$ \\
Peneda & $534 \pm 0.051^{\mathrm{b}}$ & $396 \pm 0.041^{\mathrm{a}}$ & $741 \pm 0.054^{\mathrm{b}}$ & $40.36 \pm 3.82^{\mathrm{d}}$ & $1.91 \pm 0.42^{\mathrm{a}}$ & $1.17 \pm 0.29^{\mathrm{ab}}$ & $3.08 \pm 0.65^{\mathrm{a}}$ & $184 \pm 0.021^{\mathrm{b}}$ \\
Gerês & $621 \pm 0.063^{\mathrm{c}}$ & $490 \pm 0.060^{\mathrm{b}}$ & $834 \pm 0.060^{\mathrm{c}}$ & $39.37 \pm 4.33^{\mathrm{cd}}$ & $1.81 \pm 0.38^{\mathrm{a}}$ & $1.08 \pm 0.23^{\mathrm{ab}}$ & $2.89 \pm 0.56^{\mathrm{a}}$ & $182 \pm 0.021^{\mathrm{b}}$ \\
S Estrela & $497 \pm 0.036^{\mathrm{a}}$ & $402 \pm 0.040^{\mathrm{a}}$ & $672 \pm 0.060^{\mathrm{a}}$ & $37.14 \pm 4.22^{\mathrm{bc}}$ & $1.88 \pm 0.36^{\mathrm{a}}$ & $0.99 \pm 0.15^{\mathrm{a}}$ & $2.88 \pm 0.45^{\mathrm{a}}$ & $140 \pm 0.030^{\mathrm{a}}$ \\
\hline
\end{tabular}

Wood-density components

In this study, RD values ranged from 497 $\mathrm{kg} \mathrm{m}^{-3}$ to $621 \mathrm{~kg} \mathrm{~m}^{-3}$ (Tab. 2, Tab. 4). Similar $\mathrm{RD}$ values for Pinus sylvestris were found in Spain (Rey-Prieto \& Riesco-Muñoz 2012), and Lithuania (Aleinikovas \& Grigaliûnas 2006), ranging from 491 to $586 \mathrm{~kg} \mathrm{~m}^{-3}$ (Tab. 4). Lower wood-density values were found in northern countries, namely in Sweden and in Finland, ranging from 362 to $506 \mathrm{~kg}$ $\mathrm{m}^{-3}$ (Kilpeläinen et al. 2003, Karlman et al. 2005, Fries \& Ericsson 2006, Peltola et al. 2009, Pritzkow et al. 2014). Regarding the data of the remaining studies, their comparison with our results cannot be accurate, as the measurement techniques were different, namely, the basic density (Wilhelmsson et al. 2002, Riesco-Muñoz et al. 2008, Auty et al. 2014, Tomczak et al. 2015) and green density (Verkasalo \& Leban 2002).

According to these results, we can confirm a slight downward trend in the wood density of Pinus sylvestris with increasing latitude, as previously reported by Van Der Maaten-Theunissen et al. (2013) and Rossi et al. (2015). Some of the observed exceptions, such as the high density values observed in Lithuania (Aleinikovas \& Grigaliûnas 2006) and Sweden (Karlman et al. 2005, Pritzkow et al. 2014) may be due to the older age of the trees (more than 100 years) compared to the remaining stands, which had average ages between 30 and 50 years.

Lower wood densities were found for other resinous trees, namely Pinus brutia, Abies balsamea and Picea mariana, with values ranging from 351 to $495 \mathrm{~kg} \mathrm{~m}^{-3}$ (Zhang \& Jiang 1998, Koga \& Zhang 2004, Guller et al. 2012). Although the Portuguese Scots pine stands are somewhat older (average of 55 years) than the remaining stands of other species (15 to 38 years), there is a tendency for Pinus sylvestris growing in Portugal to have slightly denser wood than resinous trees from other regions.

For Portuguese Pinus pinaster, Louzada \& Fonseca (2002) and Gaspar et al. (2008a) obtained values of 483 and $474 \mathrm{~kg} \mathrm{~m}^{-3}$ in 18/17-year-old trees, respectively. However, Louzada (1991) found RD values in 35-yearold trees similar $\left(531 \mathrm{~kg} \mathrm{~m}^{-3}\right)$ to those obtained in this study. An even higher value of $657 \mathrm{~kg} \mathrm{~m}^{-3}$ was obtained by Louzada (2000) in 70-year-old trees. Therefore, it is expected that in Portugal Pinus sylvestris wood has density values relatively lower than those of Pinus pinaster wood of similar ages.

EWD values ranged from $396 \mathrm{~kg} \mathrm{~m}^{-3}$ to $490 \mathrm{~kg} \mathrm{~m}^{-3}$ (Tab. 2, Tab. 4). For the same species, Kilpeläinen et al. (2003) and Peltola et al. (2009) found smaller EWD values in Finland, ranging from 295 to $330 \mathrm{~kg} \mathrm{~m}^{-3}$. An even lower value of $270 \mathrm{~kg} \mathrm{~m}^{-3}$ was found in Sweden by Pritzkow et al. (2014) (Tab. 4). Lower EWD values were also reported for other resinous trees, namely, Pinus brutia, Abies balsamea, and Picea mariana, ranging from 317 to $388 \mathrm{~kg} \mathrm{~m}^{-3}$ (Zhang \& Jiang 1998, Koga \& Zhang 2004, Guller et al. 2012). However, Portuguese Pinus sylvestris wood presented lower EWD values, as compared to Portuguese Pinus pinaster. Indeed, Louzada \& Fonseca (2002), and Gaspar et al. (2008a) found values of 411 and $386 \mathrm{~kg} \mathrm{~m}^{-3}$, respectively, although the sampled trees were only $18 / 17$ years old. Higher earlywood densities ranging from 452 and $519 \mathrm{~kg} \mathrm{~m}^{-3}$ were found in older trees (35/70 years - Louzada 1991, 2000).

As expected, higher density values were obtained in the latewood component (LWD), with values ranging from 672 to 841 $\mathrm{kg} \mathrm{m}^{-3}$ (Tab. 2, Tab. 4). For Pinus sylvestris, lower LWD values were found in Sweden $\left(660 \mathrm{~kg} \mathrm{~m}^{-3}\right)$ by Pritzkow et al. (2014) and in Finland ( 545 to $640 \mathrm{~kg} \mathrm{~m}^{-3}$ ) by Peltola et al. (2009) and Kilpeläinen et al. (2003 - Tab. 4). LWD values of other resinous trees, such as Pinus brutia, Abies balsamea and Picea mariana, were also lower ranging from 550 to $620 \mathrm{~kg} \mathrm{~m}^{-3}$ (Zhang \& Jiang 1998, Koga \& Zhang 2004, Guller et al. 2012).

For young Portuguese Pinus pinaster trees, Louzada \& Fonseca (2002) and Gaspar et al. (2008a) reported values of 687 and $618 \mathrm{~kg} \mathrm{~m}^{-3}$, respectively, which are relatively lower than the those obtained for mature Pinus sylvestris. Nevertheless, Louzada (1991) and Louzada (2000) found much higher values in older trees ( 781 and $892 \mathrm{~kg} \mathrm{~m}^{-3}$, respectively).

Concerning the density variability within the growth rings, the $\mathrm{HI}$ in this study varied between 140 and $219 \mathrm{~kg} \mathrm{~m}^{-3}$ (Tab. 2, Tab. 4). As for Pinus sylvestris, no data was found in literature, while a much lower $\mathrm{HI}$ was reported by Zhang \& Jiang (1998) for Picea mariana $\left(58 \mathrm{~kg} \mathrm{~m}^{-3}\right)$, and Koga \& Zhang (2004) for Abies balsamea (79 kg m $\mathrm{kg}^{-3}$ - Tab. 4). A lower HI was also found in 18/17-yearold Pinus pinaster (134 and $120 \mathrm{~kg} \mathrm{~m}^{-3}$, respectively) by Louzada \& Fonseca (2002) and Gaspar et al. (2008a). However, in older trees (35/70 years), the $\mathrm{HI}$ was higher, ranging from 140 to $185 \mathrm{~kg} \mathrm{~m}^{-3}$ (Louzada 1991, 2000), similar to mature Pinus sylvestris.

The results obtained in this and other studies regarding growth components are compiled in Tab. 5. Regarding the ringwidth components, RW varied between

Tab. 3 - Mean values ( \pm standard deviation) and results of the comparison test for chemical and mechanical properties. (Dichloro): extractives soluble in dichloromethane (\%); (Ethanol): extractives soluble in ethanol (\%); (Water): extractives soluble in water (\%); (Total): total extractives (\%); (Klason): lignin content (\%); $(\mathrm{H} / \mathrm{G})$ : lignin composition (\%); (cP/cH): pentose/hexose ratio; $\left(\mathrm{MOE}_{\mathrm{Rad}}\right)$ : radial modulus of elasticity $(\mathrm{MPa}) ;\left(\mathrm{MOR}_{\text {Rad }}\right)$ : radial modulus of rupture (MPa). Different letters in the same column indicate significant differences $(p<0.05)$ between sampled sites after Duncan's multiple range test.

\begin{tabular}{|c|c|c|c|c|c|c|c|c|c|}
\hline Site & Dichloro & Ethanol & Water & Total & Klason & H/G & $\mathrm{cP} / \mathrm{cH}$ & $\mathrm{MOE}_{\mathrm{Rad}}$ & $\mathrm{MOR}_{\mathrm{Rad}}$ \\
\hline Marão & $8.41 \pm 2.30^{\mathrm{a}}$ & $2.19 \pm 0.13^{\mathrm{a}}$ & $0.53 \pm 0.15^{\mathrm{a}}$ & $11.12 \pm 2.40^{\mathrm{a}}$ & $26.87 \pm 0.68^{\mathrm{a}}$ & $0.042 \pm 0.006^{a}$ & $10.91 \pm 0.63^{\mathrm{a}}$ & $1398.10 \pm 564.74^{b}$ & $34.93 \pm 12.17^{c}$ \\
\hline Vinhais & $12.41 \pm 4.90^{\mathrm{b}}$ & $2.18 \pm 0.23^{\mathrm{a}}$ & $0.82 \pm 0.20^{\mathrm{b}}$ & $15.41 \pm 4.94^{\mathrm{b}}$ & $27.67 \pm 0.62^{\mathrm{b}}$ & $0.048 \pm 0.004^{b}$ & $12.35 \pm 1.34^{\mathrm{b}}$ & $909.45 \pm 306.62^{\mathrm{a}}$ & $23.60 \pm 5.62^{\mathrm{a}}$ \\
\hline Peneda & $7.59 \pm 3.77^{\mathrm{a}}$ & $2.24 \pm 0.24^{\mathrm{a}}$ & $0.88 \pm 0.33^{b}$ & $10.72 \pm 3.75^{\mathrm{a}}$ & $27.58 \pm 0.56^{\mathrm{b}}$ & $0.047 \pm 0.005^{b}$ & $11.94 \pm 1.24^{\mathrm{b}}$ & $969.49 \pm 300.45^{\mathrm{a}}$ & $23.74 \pm 5.55^{\mathrm{a}}$ \\
\hline Gerês & $10.60 \pm 6.99^{\mathrm{ab}}$ & $2.29 \pm 0.19^{a}$ & $0.81 \pm 0.27^{b}$ & $13.85 \pm 7.16^{\mathrm{ab}}$ & $27.59 \pm 0.56^{\mathrm{b}}$ & $0.048 \pm 0.004^{b}$ & $11.97 \pm 1.56^{\mathrm{b}}$ & $1504.02 \pm 307.74^{b}$ & $30.76 \pm 5.20^{\mathrm{bc}}$ \\
\hline S Estrela & $11.96 \pm 4.99^{b}$ & $2.22 \pm 0.22^{\mathrm{a}}$ & $0.81 \pm 0.28^{\mathrm{b}}$ & $14.99 \pm 4.91^{\mathrm{b}}$ & $27.81 \pm 0.68^{\mathrm{b}}$ & $0.048 \pm 0.004^{b}$ & $13.23 \pm 1.22^{c}$ & $1046.18 \pm 219.95^{\mathrm{a}}$ & $27.50 \pm 4.78^{\mathrm{ab}}$ \\
\hline
\end{tabular}


Tab. 4 - Comparison of the results of this study with data from literature regarding density components in softwoods. (X-ray md): Xray microdensitometry.

\begin{tabular}{|c|c|c|c|c|c|c|c|c|c|c|}
\hline Species & Reference & Country & $\begin{array}{l}\text { Altitude } \\
\text { (m a.s.l.) }\end{array}$ & $\begin{array}{l}\text { Latitude } \\
\left({ }^{\circ} \mathrm{N}\right)\end{array}$ & $\begin{array}{l}\text { Age } \\
\text { (yrs) }\end{array}$ & $\begin{array}{l}\text { Measurement } \\
\text { technique }\end{array}$ & $\begin{array}{c}\mathrm{RD} \\
\left(\mathrm{kg} \mathrm{m}^{-3}\right)\end{array}$ & $\begin{array}{c}\text { EWD } \\
\left(\mathrm{kg} \mathrm{m}^{-3}\right)\end{array}$ & $\begin{array}{l}\text { LWD } \\
\left(\mathrm{kg} \mathrm{m}^{-3}\right)\end{array}$ & $\begin{array}{c}\mathrm{HI} \\
\left(\mathrm{kg} \mathrm{m}^{-3}\right)\end{array}$ \\
\hline \multirow[t]{14}{*}{ Pinus sylvestris } & Present study & Portugal & $815-1424$ & $40-41$ & $46-66$ & X-ray md & $497-621$ & $396-490$ & $672-841$ & $140-219$ \\
\hline & Riesco-Muñoz et al. (2008) & Spain & $500-700$ & $42-43$ & $28 / 44$ & Basic density & 487 & - & - & - \\
\hline & $\begin{array}{l}\text { Rey-Prieto \& Riesco-Muñoz } \\
\text { (2012) }\end{array}$ & Spain & $500-1100$ & $42-43$ & $20-32$ & $\begin{array}{l}\text { Density at } \\
12 \% \mathrm{MC}\end{array}$ & 491 & - & - & - \\
\hline & Verkasalo \& Leban (2002) & France & - & 48 & 34 & Green density & 532 & - & - & - \\
\hline & Tomczak et al. (2015) & Poland & $100-200$ & $53-54$ & - & Basic density & 398 & - & - & - \\
\hline & $\begin{array}{l}\text { Aleinikovas \& Grigaliûnas } \\
\text { (2006) }\end{array}$ & Lithuania & $50-120$ & $54-55$ & $85-110$ & $\begin{array}{l}\text { Density at } \\
12 \% M C\end{array}$ & $572-586$ & - & - & - \\
\hline & Auty et al. (2014) & Scotland & $10-300$ & 57 & $9-99$ & Basic density & 423 & - & - & - \\
\hline & Wilhelmsson et al. (2002) & Sweden & 222 & 61 & 68 & Basic density & 398 & - & - & - \\
\hline & Verkasalo \& Leban (2002) & Finland & - & $60-65$ & 40 & Green density & 488 & - & - & - \\
\hline & Karlman et al. (2005) & Sweden & $100-200$ & 60 & $100-145$ & X-ray md & $502-506$ & - & - & - \\
\hline & Kilpeläinen et al. (2003) & Finland & 145 & 62 & 15 & X-ray md & 410 & 330 & 640 & - \\
\hline & Fries \& Ericsson (2006) & Sweden & 320 & 63 & 30 & X-ray md & 450 & - & - & - \\
\hline & Peltola et al. (2009) & Finland & 85 & 63 & 20 & X-ray md & $362-373$ & 295-305 & $545-567$ & - \\
\hline & Pritzkow et al. (2014) & Sweden & $350-450$ & 68 & $50-339$ & X-ray md & 460 & 270 & 660 & - \\
\hline Pinus brutia & Guller et al. (2012) & Turkey & $90-350$ & 36 & 30 & X-ray md & 495 & 388 & 620 & - \\
\hline Picea mariana & Zhang \& Jiang (1998) & Canada & $100-300$ & 46 & 15 & X-ray md & 405 & 380 & 550 & 58 \\
\hline Abies balsamea & Koga \& Zhang (2004) & Canada & $200-300$ & 47 & 38 & X-ray md & 351 & 317 & 564 & 79 \\
\hline \multirow[t]{4}{*}{ Pinus pinaster } & Gaspar et al. (2008a) & Portugal & 30 & 39 & 17 & X-ray md & 474 & 386 & 618 & 120 \\
\hline & Louzada \& Fonseca (2002) & Portugal & 750 & 41 & 18 & X-ray md & 483 & 411 & 687 & 134 \\
\hline & Louzada (1991) & Portugal & $400-800$ & $41-42$ & 35 & X-ray md & 531 & $452-463$ & $758-795$ & $140-155$ \\
\hline & Louzada (2000) & Portugal & $40-600$ & $39-41$ & 70 & X-ray md & 657 & 519 & 859 & 185 \\
\hline
\end{tabular}

2.86 and $3.72 \mathrm{~mm}$ in this study, while its components EWW and LWW ranged from 1.81 to $2.52 \mathrm{~mm}$ and from 0.99 to $1.21 \mathrm{~mm}$, respectively (Tab. 2, Tab. 5). Similar RW values for the same species were found in France (3.57 mm - Verkasalo \& Leban 2002), and Scotland (Auty et al. 2014), where RW values ranged from 1.9 to $3.7 \mathrm{~mm}$ (Tab. 5). In general, Pinus sylvestris wood from northern European countries presented lower RW values, ranging from 1.11 to 1.89 $\mathrm{mm}$ (Wilhelmsson et al. 2002, Verkasalo \& Leban 2002, Karlman et al. 2005, Aleiniko- vas \& Grigaliûnas 2006, Pritzkow et al. Pinus pinaster ( 4.22 to $5.13 \mathrm{~mm}$ ) in younger 2014). The exception is reported by Peltola trees with ages from 15 to 18 years (Zhang et al. (2009) for Scots pine in Finland, with \& Jiang 1998, Louzada \& Fonseca 2002, RW values of 3.0 to $3.6 \mathrm{~mm}$, although in Gaspar et al. 2008a). A similar pattern of trees with only 20-year-old.

Comparing to other softwood species, the RW values of Scots pine wood obtained in this study were similar to those found in Pinus brutia, Abies balsamea, and Pinus pinaster, ranging from 2.06 to 3.51 $\mathrm{mm}$ (Louzada 1991, 2000, Koga \& Zhang 2004, Guller et al. 2012). Exceptions were found for Picea mariana $(4.03 \mathrm{~mm})$ and variation was detected for EWW and LWW components (Tab. 5). Concerning LWP, values ranged from $33.3 \%$ to $40.3 \%$ (Tab. 2, Tab. 5). These values are similar to those reported in Pinus sylvestris, Pinus brutia, and Pinus pinaster, ranging from $24 \%$ to 46.9\% (Louzada 1991, 2000, Louzada \& Fonseca 2002, Karlman et al. 2005, Aleinikovas \& Grigaliûnas 2006, Gaspar et al. 2008a,

Tab. 5 - Comparison of the results of this study with data from literature regarding growth components in softwoods.

\begin{tabular}{|c|c|c|c|c|c|c|c|c|c|}
\hline Species & Reference & Country & $\begin{array}{l}\text { Altitude } \\
\text { (m a.s.l.) }\end{array}$ & $\begin{array}{c}\text { Latitude } \\
\left({ }^{\circ} \mathrm{N}\right)\end{array}$ & $\begin{array}{l}\text { Age } \\
\text { (yrs) }\end{array}$ & $\begin{array}{c}\text { RW } \\
(\mathrm{mm})\end{array}$ & $\begin{array}{l}\text { EWW } \\
(\mathrm{mm})\end{array}$ & $\begin{array}{l}\mathrm{LWW} \\
(\mathrm{mm})\end{array}$ & $\begin{array}{c}\text { LWP } \\
(\%)\end{array}$ \\
\hline \multirow[t]{9}{*}{ Pinus sylvestris } & Present study & Portugal & $815-1424$ & $40-41$ & $46-66$ & $2.86-3.72$ & $1.81-2.52$ & $0.99-1.21$ & $33.3-40.3$ \\
\hline & Verkasalo \& Leban (2002) & France & - & 48 & 34 & 3.57 & - & - & - \\
\hline & Aleinikovas \& Grigaliûnas (2006) & Lithuania & $50-120$ & $54-55$ & $85-110$ & $1.64-1.89$ & - & - & $34.7-38.6$ \\
\hline & Wilhelmsson et al. (2002) & Sweden & 222 & 61 & 68 & 1.64 & - & - & - \\
\hline & Verkasalo \& Leban (2002) & Finland & - & $60-65$ & 40 & 1.81 & - & - & - \\
\hline & Auty et al. (2014) & Scotland & $10-300$ & 57 & $9-99$ & $1.9-3.7$ & - & - & - \\
\hline & Karlman et al. (2005) & Sweden & $100-200$ & 60 & $100-145$ & $1.11-1.58$ & - & - & 39 \\
\hline & Peltola et al. (2009) & Finland & 85 & 63 & 20 & $3.0-3.6$ & - & - & $24-28$ \\
\hline & Pritzkow et al. (2014) & Sweden & $350-450$ & 68 & $50-339$ & 1.4 & - & - & - \\
\hline Pinus brutia & Guller et al. (2012) & Turkey & $90-350$ & 36 & 30 & 2.93 & 1.58 & 1.38 & 46.9 \\
\hline Picea mariana & Zhang \& Jiang (1998) & Canada & $100-300$ & 46 & 15 & 4.03 & 3.51 & 0.52 & 14.1 \\
\hline Abies balsamea & Koga \& Zhang (2004) & Canada & $200-300$ & 47 & 38 & 2.06 & 1.82 & 0.24 & 11.8 \\
\hline \multirow[t]{4}{*}{ Pinus pinaster } & Gaspar et al. (2008a) & Portugal & 30 & 39 & 17 & 4.22 & 2.7 & 1.5 & 38.2 \\
\hline & Louzada \& Fonseca (2002) & Portugal & 750 & 41 & 18 & 5.13 & 3.8 & 1.3 & 25.9 \\
\hline & Louzada (1991) & Portugal & $400-800$ & $41-42$ & 35 & 3.51 & 2.4 & 1.1 & 32.8 \\
\hline & Louzada (2000) & Portugal & $40-600$ & $39-41$ & 70 & 2.21 & 1.3 & 0.9 & 40.5 \\
\hline
\end{tabular}


Peltola et al. 2009, Guller et al. 2012). Lower LWP values were found for Abies balsamea (11.8\%) and Picea mariana (14.1\%) wood (Zhang \& Jiang 1998, Koga \& Zhang 2004), as usual in these species.

Based on the above results, we can con clude that the observed differences in radial growth are mainly due to the geographic provenance and to the effect of age. Nevertheless, in comparison to Portuguese Pinus pinaster wood, Pinus sylvestris had similar or slightly lower growth than $P$. pinaster trees of similar ages.

Density and RW variations among species and sites have been thoroughly investigated in the past. Nevertheless, even today knowledge gaps in this sector hamper the establishment of a comprehensive theory to explain these differences. Zobel \& Van Buijtenen (1989) justify the wide variety of results by the fact that sites cannot be quantified biologically and by their dependence on the interaction of various factors (e.g., soil, nutrients, moisture, photoperiod, etc.), whose unique local combinations largely affects wood type and characteristics.

\section{Chemical properties of wood}

The average content of total extractives per site observed in this study (15.41 to $10.72 \%$ - Tab. 3) was outside the range of 25\% attributed to softwoods (Sjöström \& Alén 2013). However, the comparison with literature data should be done with caution due to differences among different studies in extraction procedures, solvents used, time of extraction, and tree age. In Latvia, Sable et al. (2012) found less total extractives (2.9\%) in 27-year-old Pinus sylvestris. In young Pinus pinaster (17 years) values of $4.2 \%$ to $6.1 \%$ were found in Portugal (Fernandes 2006, Gaspar et al. 2011). For 14year-old French Pinus pinaster, Da Silva Perez et al. (2007) found $4.8 \%$ total extractives. The effect of tree age on extractive content is remarkable, since the nature and amount of extractives are dependent on the heartwood content and thus on wood age. There is a gradual increase with tree ageing in the resin content of the inner heartwood, mainly in the lower part of the stem. This means that mature trees contain more heartwood than younger trees, and therefore exhibit a higher extractive content. Although the sampled trees in this study (average age of 56 years) are older than those in the cited works, the obtained values are too higher to be explained only by differences in tree age. Hence, we can conclude that Portuguese Pinus sylvestris wood has a higher extractive content than other European softwoods.

In this study, dichloromethane removed a higher percentage of extractives (12.41 to $7.59 \%$ ) than ethanol (2.29 to $2.18 \%$ ) and water ( 0.53 to $0.96 \%$ - Tab. 3). Contrastingly, Fernandes (2006), Da Silva Perez et al. (2007), and Gaspar et al. (2011) found that in Pinus pinaster, water extractives accounted for the largest part of total extrac- tives ( $1.8 \%$ to $3.2 \%$ ), followed by dichloromethane (1.6\%) and ethanol (1.2\%).

Klason lignin varied from 26.9 to $27.8 \%$ between sites (Tab. 3), within the range of $25 \%$ to $33 \%$ attributed to softwoods (Sjöström \& Alén 2013). For the same species, similar lignin content values were found for 27- to 30-year-old Pinus sylvestris in Latvia (27.1\% - Sable et al. 2012) and Finland (18.8\% to $26.6 \%$ - Toivanen \& Alén 2006). For Pinus pinaster, values ranging from 25.6 to $35.3 \%$ were reported for 12- to 14-year-old trees (Alves et al. 2006, Fernandes 2006, Da Silva Perez et al. 2007, Gaspar et al. 2011).

Our results shows that there was a small variation in the $\mathrm{H} / \mathrm{G}$ ratio between sites (0.042 to 0.048 - Tab. 3). Similar values were found for Pinus pinaster (0.041-0.113) by Alves et al. (2006) and Da Silva Perez et al. (2007). In fact, average lignin content of wood is less variable within species, often with a range of only a few percent (Sjöström \& Alén 2013), and seems to be under moderate genetic control (Gaspar et al. 2011). However, the earlywood within a tree tends to have a slightly higher lignin concentration than latewood (Donaldson 1985). According to Donaldson (1985), the middle lamella accounts for a slightly higher part of total cell-wall volume in earlywood than in latewood and has a higher lignin concentration than the rest of the wall. Changes in thickness of the $S_{2}$ layer will induce differences in wall thickness between earlywood and latewood, which could account for the change in the cellulose/lignin ratio (Donaldson 1985). Lignin content of inner wood near the pith is greater than that of outer wood. Latewood has thicker walls in mature wood (Donaldson 1985), and there is higher latewood content in outer wood than in inner wood. Basically, changes in fibre morphology and cell-wall thickness account for the observed variation in chemical composition.

It is worth noting that, when data from different sources are compared, the differences between methodologies, harvest age, and the possible contribution of compression wood must be taken into account. Lignin content is influenced by this kind of wood since compression wood contains more lignin and less cellulose than normal wood (Tsoumis 1991). For this reason, special care was taken during the sampling process to avoid compression wood.

\section{Mechanical properties of wood}

$M O E_{\text {Rad }}$ and $M_{\text {Rad }}$ values ranged from 0.9 to $1.5 \mathrm{GPa}$ and from 23.6 to $34.93 \mathrm{MPa}$, respectively (Tab. 3). Few studies of mechanical traits on radial direction were found in the literature. For Pinus pinaster, Fernandes (2006) and Gaspar et al. (2011) obtained similar average values for $\mathrm{MOE}_{\text {Rad }}$ (1.37 and $1.10 \mathrm{GPa}$, respectively) but lower values for $M_{\text {Rad }}$ (14.1 and $13.7 \mathrm{MPa}$, respectively). Even lower MOR ${ }_{\text {Rad }}$ values were reported by Ohbayashi et al. (2001) for Pinus radiata (7.3-7.8 MPa), also in the radial direction. It should be noted that these results were reported in much younger trees (20 to 25 years) than those analyzed in this study (46 to 66 years). Nonetheless, Portuguese Pinus sylvestris wood seems to have high stiffness and strength as compared with other softwoods, although the available data is not extensive.

\section{Comparisons among Portuguese sampling sites}

\section{Wood-density components}

The largest differences in RD among sampling sites in Portugal were found between Gerês, with the highest value $\left(621 \mathrm{~kg} \mathrm{~m}^{-3}\right)$, and Serra da Estrela, with the lowest value $\left(497 \mathrm{~kg} \mathrm{~m}^{-3}\right)$. There were no significant differences in RD among the remaining sites, with values ranging from 534 to $548 \mathrm{~kg} \mathrm{~m}^{-3}$ (Tab. 2). Gerês also presented the highest EWD $\left(490 \mathrm{~kg} \mathrm{~m}^{-3}\right)$, standing out from other sites where the differences in EWD were not significant. EWD values varied from $396 \mathrm{~kg} \mathrm{~m}^{-3}$ in Peneda to $421 \mathrm{~kg} \mathrm{~m}^{-3}$ in Vinhais.

The highest LWD values were observed in wood samples from Marão $\left(841 \mathrm{~kg} \mathrm{~m}^{-3}\right)$ and Gerês $\left(834 \mathrm{~kg} \mathrm{~m}^{-3}\right)$ and were significantly different from values obtained at the other sites. Between Vinhais and Peneda, no significant differences were found, with LWD values of 774 and $741 \mathrm{~kg} \mathrm{~m}^{-3}$, respectively. Serra da Estrela presented the lowest LWD $\left(672 \mathrm{~kg} \mathrm{~m}^{-3}\right)$, which is significantly different from the LWD values of wood samples taken at other sites.

According to these results, no trends related to latitude were detected, as the sites with higher density (Gerês and Marão) are located at an intermediate position in respect to sites with lower density (Peneda and Serra da Estrela - Fig. 1). However, a decrease in wood density was observed with increasing elevation. Indeed, the sites with higher density (Gerês and Marão) are situated at lower altitudes, while the remaining sites with lower density are situated at higher altitudes.

Regarding RW, wood samples from Marão were significantly different from those sampled at the other sites. Marão exhibited higher RW $(3.72 \mathrm{~mm})$, mainly due to high EWW values. The differences among the remaining sites were not significant, with values ranging from 2.86 to $3.08 \mathrm{~mm}$. The higher radial growth observed in Marão is manifested in both EWW and LWW. Relative to the other sites, significant differences were observed neither for EWW nor LWW.

In terms of LWP, Peneda and Gerês achieved the highest values $(40.36 \%$ and $39.37 \%$ ), which were significantly different from the other sites. The differences among the remaining sites were smaller, ranging from $33.26 \%$ to $37.14 \%$.

Regarding $\mathrm{HI}$, greater differences were observed between wood samples from Marão, which showed the highest value 
(219 $\mathrm{kg} \mathrm{m}^{-3}$ ), and those from Serra da Estrela, which showed the lowest (140 kg $\mathrm{m}^{-3}$ ). Among the other sites no significant differences were observed for $\mathrm{HI}$, with values of $182 \mathrm{~kg} \mathrm{~m}^{-3}$ to $184 \mathrm{~kg} \mathrm{~m}^{-3}$.

Greater differences in wood density and radial growth are expected when differences between sites are conspicuous, particularly in terms of latitude and altitude (Gindl et al. 2001, Van Der Maaten-Theunissen et al. 2013, Rossi et al. 2015), which are inherently related to temperature, precipitation (quantity and distribution), and photoperiod (Zobel \& Van Buijtenen 1989, Kurz-Besson et al. 2016). Based on the results of this study, it can be highlighted that Marão reconciles high radial growth with high density.

\section{Chemical properties of wood}

Wood samples from Vinhais and Serra da Estrela exhibited the highest values of total extractives content (15.41\% and $14.99 \%$, respectively) while the lowest values were found in Peneda (10.72\%) and Marão (11.12\% - Tab. 3). This variation pattern among sites is mainly due to dichloromethane extractives; Vinhais and Serra da Estrela presented the highest values $(15.41 \%$ and $14.99 \%$, respectively), and Peneda and Marão presented the lowest ones (12.41\% and $11.96 \%$, respectively). For ethanol and water extraction, the differences among sites were very small and not statistically significant.

Concerning lignin content (Klason), its composition $(\mathrm{H} / \mathrm{G})$ and the pentosans/hexosans ratio $(\mathrm{CP} / \mathrm{CH})$, the range of values observed in our analysis was small. Marão samples presented the lowest values (26.87\%, 0.042 and 10.91 , respectively), which are statistically different from values from the other sites. No significant differences were observed among the remaining sites (27.58\% to $27.81 \%, 0.047$ to 0.048 and 11.94 to 13.23 , respectively). These results confirm that the within-species variation of average lignin content of wood is fairly low (Sjöström \& Alén 2013).

The effect of altitude on Norway spruce wood was studied by Gindl et al. (2001), who found that lignin content was higher at higher elevations. The authors hypothesized that trees growing at higher altitudes compensate for thinner cell walls by increasing the lignin content in order to maintain the mechanical integrity of the xylem. In fact, in this study samples from higher altitude sites (Serra da Estrela and Vinhais) presented a somewhat higher lignin content (27.81 and $27.67 \%$ ) than those from low altitude sites.

\section{Radial mechanical properties of wood}

The high values of $M O E_{\text {Rad }}$ and $M O R_{\text {Rad }}$ obtained for Gerês (1504.02 and 30.76 $\mathrm{MPa}$ ) and Marão (1398.10 and $34.93 \mathrm{MPa}$ ) are significantly different from those of the other sites (Tab. 3). No significant differences were found among the values of the remaining sites.

Such as for wood density, the results indicate that mechanical properties of wood are higher in sites located at lower altitudes. Similar results were also noted by Rossi et al. (2015) for black spruce.

\section{Correlations between wood-quality traits}

The correlation matrix for wood-density components and chemical and mechanical properties is presented in Tab. 6 .

\section{Wood density and growth components}

The results in Tab. 6 show highly significant correlations among the measured density components. The correlation between RD and EWD ( $r=0.915)$ was slightly stronger than between RD and LWD $(r=0.780)$. Both earlywood and latewood densities were also positively correlated but to a lesser extent $(r=0.557)$. The same behavior was verified by Peltola et al. (2009) for Pinus sylvestris, where the correlation between ring density and earlywood density ( $r=0.85-0.79)$ was higher than between overall density and latewood density $(r=0.75-0.66)$. There was also a moderate correlation between earlywood and latewood densities ( $r=0.51-0.45)$. Additionally, Koubaa et al. (2007) found similar results in Picea mariana, where the correlation bewteen RD and EWD ( $r=0.87-0.91)$ was higher than the correlation between $R D$ and LWD ( $r=0.58-0.54)$, and there was a moderate correlation between EWD and LWD ( $r=0.28-0.43)$. For Pinus pinaster, Louzada (2003) also noticed a more important dependency of RD on EWD ( $r=0.959-0.960)$ than on LWD ( $r=0.521-0.708)$ and a moderate correlation between earlywood and latewood densities ( $r=0.291-0.507)$. On the other hand, Gaspar et al. (2008b), also for Pinus pinaster, found a higher correlation of RD to LWD ( $r=0.72)$ than to EWD ( $r=$ 0.67 ) and a weak but positive correlation between earlywood and latewood densities ( $r=0.19)$. Abdel-Gadir et al. (1993) stated that for Pseudotsuga menziesii in the juvenile period, RD was positively, moderately, and equally correlated with EWD and LWD $(r=0.56)$, but in mature wood, the correlation was slightly higher with LWD $(r=0.72)$.

As expected, LWP was significantly highly correlated with RD ( $r=0.419$ - Tab. 6). For Picea abies, Steffenrem et al. (2007) also found similar positive correlations between these traits at the individual tree level $(r=0.50)$. For Pinus pinaster, Louzada (2003) and Gaspar et al. (2008b) found a much higher correlation of LWP to RD ( $r=0.955^{-}$

Tab. 6 - Pearson's correlation matrix between wood-density components and chemical and mechanical properties, computed at tree level (100 observations). Significance level (100 obs.): highly significant ( $r>0.321)$, very significant $(r>0.254)$, significant $(r>0.195)$.

\begin{tabular}{|c|c|c|c|c|c|c|c|c|c|c|c|c|c|c|c|c|}
\hline - & $\sum_{\mathrm{w}}^{\mathrm{O}}$ & 主 & 号 & 引 & 3 & z & $\overline{\mathbf{x}}$ & $\frac{\grave{o}}{\frac{U}{u}}$ & 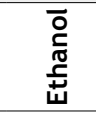 & $\frac{\grave{\Phi}}{\stackrel{ \pm}{\pi}}$ & 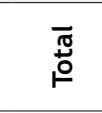 & 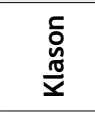 & ણ & $\frac{\mathrm{I}}{\mathrm{U}}$ & 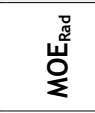 & 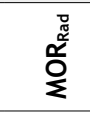 \\
\hline $\mathrm{RD}$ & 0.915 & 0.780 & 0.419 & -0.208 & 0.175 & -0.079 & 0.243 & -0.049 & -0.068 & 0.073 & -0.047 & -0.140 & -0.063 & -0.199 & 0.482 & 0.323 \\
\hline EWD & - & 0.557 & 0.357 & -0.347 & -0.054 & -0.269 & -0.123 & 0.030 & -0.015 & 0.167 & 0.039 & -0.019 & 0.038 & -0.073 & 0.410 & 0.254 \\
\hline LWD & - & - & -0.069 & 0.219 & 0.249 & 0.255 & 0.743 & -0.061 & -0.154 & -0.183 & -0.077 & -0.344 & -0.182 & -0.307 & 0.499 & 0.443 \\
\hline LWP & - & - & - & -0.480 & 0.304 & -0.222 & -0.231 & -0.134 & 0.072 & 0.257 & -0.115 & 0.159 & 0.037 & -0.068 & 0.074 & -0.097 \\
\hline EWW & - & - & - & - & 0.590 & 0.947 & 0.489 & -0.092 & -0.143 & -0.404 & -0.119 & -0.355 & -0.337 & -0.036 & 0.098 & 0.283 \\
\hline LWW & - & - & - & - & - & 0.818 & 0.404 & -0.036 & -0.127 & -0.280 & -0.056 & -0.247 & -0.276 & -0.013 & 0.146 & 0.224 \\
\hline $\mathrm{RW}$ & - & - & - & - & - & - & 0.509 & -0.080 & -0.152 & -0.399 & -0.107 & -0.351 & -0.350 & -0.031 & 0.128 & 0.291 \\
\hline $\mathrm{HI}$ & - & - & - & - & - & - & - & -0.131 & -0.164 & -0.318 & -0.155 & -0.369 & -0.241 & -0.337 & 0.267 & 0.297 \\
\hline Diclor & - & - & - & - & - & - & - & - & 0.144 & 0.027 & 0.996 & 0.270 & 0.364 & 0.250 & -0.029 & -0.091 \\
\hline Ethanol & - & - & - & - & - & - & - & - & - & 0.550 & 0.214 & 0.259 & 0.357 & -0.096 & -0.051 & -0.118 \\
\hline Water & - & - & - & - & - & - & - & - & - & - & 0.105 & 0.633 & 0.557 & 0.187 & -0.057 & -0.239 \\
\hline Total & - & - & - & - & - & - & - & - & - & - & - & 0.314 & 0.405 & 0.254 & -0.033 & -0.108 \\
\hline Klason & - & - & - & - & - & - & - & - & - & - & - & - & 0.726 & 0.290 & -0.273 & -0.323 \\
\hline $\mathrm{H} / \mathrm{G}$ & - & - & - & - & - & - & - & - & - & - & - & - & - & 0.182 & -0.216 & -0.294 \\
\hline $\mathrm{cP} / \mathrm{cH}$ & - & - & - & - & - & - & - & - & - & - & - & - & - & - & -0.153 & -0.116 \\
\hline $\mathrm{MOE}_{\mathrm{Rad}}$ & - & - & - & - & - & - & - & - & - & - & - & - & - & - & - & 0.779 \\
\hline
\end{tabular}


0.972 and 0.90 , respectively) as did Koubaa et al. (2007) for Picea mariana for both plantations $(r=0.93-0.88)$ and juvenile and mature wood ( $r=0.91-0.86)$. Further, AbdelGadir et al. (1993) stated that for Pseudot suga menziesii, RD had a very strong correlation with LWP ( $r=0.93-0.94)$, suggesting that variation in RD and LWP depends on almost the same set of factors.

LWP was also significantly highly corre lated with EWD $(r=0.357)$, but the correlation with LWD was small, negative, and not significant $(r=-0.069)$. Contrary to our re sults, Louzada (2003) found a positive correlation between LWP and LWD $(r=0.575$ $0.794)$ and an even higher correlation be tween LWP and EWD ( $r=0.845-0.891)$. Similar results were found by Koubaa et al (2007). Abdel-Gadir et al. (1993) also achieved moderate positive correlations of LWP to density-related components ( $r=$ 0.38 to 0.63 ). Gaspar et al. (2008b) also found a moderately positive correlation between these traits, although the correlation was slightly higher for LWD $(r=0.59)$ than for EWD ( $r=0.49)$.

Concerning ring width components, LWP showed a highly significant correlation to LWW ( $r=0.304)$, but a stronger, negative correlation to EWW ( $r=-0.480)$. This mean that an increase of LWP depends more on a EWW decrease, which is reflected in the negative correlation between RW and LWP $(r=-0.222)$. For the same species, Peltola et al. (2009) also found a strong negative correlation between LWP and EWW ( $r=-0.72)$, higher than the positive correlation with LWW ( $r=0.29)$, which led to a negative correlation with RW ( $r=-0.57)$.

For Picea mariana, Koubaa et al. (2007) also found negative correlations of LWP to RW ( $r=-0.53$ to -0.35$)$ and EWW ( $r=-0.75$ to $-0.68)$ but strong positive correlations to LWW ( $r=0.71-0.83$ ). Gaspar et al. (2008b) also found a positive correlation of LWP to LWW $(r=0.87)$ and a negative correlation of LWP to EWW ( $r=-0.76)$. Similarly, AbdelGadir et al. (1993) found positive correlations of LWP to LWW ( $r=0.65-0.59)$ and negative correlations of LWP to EWW ( $r$ -0.14 to -0.67 ). However, the correlations of LWP to RW were positive in juvenile wood $(r=0.15)$ and negative in mature wood $(r=-0.11)$. On the other hand, Louzada (2003) found a positive but very small correlation between LWP and RW ( $r=0.009$ to 0.091).

For Pinus sylvestris wood, it has been demonstrated that the increase of LWP is more dependent on the decrease of EWW than on the increase of LWW. It is likely that the reported differences related to LWP may result from the different methodologies used to define the threshold value between EW and LW.

RW had a slightly higher correlation with earlywood width (EWW - $r=0.947$ ) than LWW ( $r=0.818)$, but both are highly significant (Tab. 6). Similar results were obtained by Peltola et al. (2009) for Scots pine at two different sites for EWW ( $r=0.98-0.97)$ and LWW ( $r=0.60-0.75)$. Abdel-Gadir et al. (1993) denoted the same behavior in both juvenile and mature wood of Pseudotsuga menziesii for EWW ( $r=0.96-0.80)$ and LWW $(r=0.84-0.72)$. Koubaa et al. (2007) obtained much higher correlations of RW to EWW ( $r=0.95-0.91)$ compared to the low values of LWW $(r=0.14-0.19)$ for both plantations and for both juvenile and mature wood ( $r=0.95-0.96$ and $r=0.13-0.55$, respectively). For Abies balsamea, Koga \& Zhang (2004) also reported a strong positive correlation between RW and EWW $(r=0.96)$ but no correlation between RW and LWW $(r=0.05)$, meaning that the larger radial growth was caused by an increase in EWW.

This significant influence of Pinus sylvestris earlywood on RW is then reflected in the negative correlation found between RW and LWP ( $r=-0.222)$ as well as RD ( $r=$ -0.079). However, since the latter correlation is one of the smallest observed and is not statistically significant, it can be deduced that higher radial growth (RW) does not have a pronounced negative influence on density. Peltola et al. (2009), also for Pinus sylvestris, found a negative and very low correlation of WD to RW for one site $(r=-0.05)$, and a stronger and negative correlation for the other site $(r=-0.42)$. Further, Fries \& Ericsson (2006) found that for Pinus sylvestris, correlations of density with diameter were quite strong and negative, in accordance with the assumption that wide rings tend to have lower density than narrow rings. For other resinous trees, $A b$ del-Gadir et al. (1993) reported a weak and negative correlation between RD and RW ( $r=-0.06$ to 0.04 ) in Pseudotsuga menziesii. For Picea mariana, Koubaa et al. (2007) found stronger negative relationships between growth rate (RW) and wood density (RD) in both plantations and for both juvenile and mature wood ( $r=-0.29$ to -0.44$)$. For Abies balsamea, Koga \& Zhang (2004) also noticed a negative correlation between RD and RW ( $r=-0.48)$. Steffenrem et al. (2007) found similar results for Picea abies in all levels studied. On the other hand, Louzada (2003) found a small but positive correlation of RW to RD ( $r=0.028$ to 0.180 ) in Pinus pinaster. However, according to Karenlampi \& Riekkinen (2004 cited in Auty 2006), an increased growth rate, which is generally associated with lower wood density, may not apply for Pinus sylvestris, since growth rate and density have been shown to be independent, with the density influenced more by cambial age than distance from the tree pith.

$\mathrm{RD}$ was also correlated negatively with EWW ( $r=-0.208)$ but positively with LWW although these correlations are not significant $(r=0.175)$. This behavior has also been noted in other studies (Abdel-Gadir et al. 1993, Koubaa et al. 2007, Gaspar et al. 2008b, Peltola et al. 2009).

Our review of the available literature highlighted a lack of consensus on the relationship between wood density and growth traits, as positive, neutral, and neg- ative correlations can be found. In addition, Zobel \& Van Buijtenen (1989) compiled information on this subject, finding that all types of correlations between growth rate and specific gravity can be found in the literature. However, it is important to point out that to evaluate the real influence of growth rate on wood density, the analyses has to be conducted among homogeneous age classes. According to Zobel \& Van Buijtenen (1989) relating wood properties to RW for rings of different ages results in false and controversial ideas on the effect of growth rate and can be a factor that contributes to the multiplicity of results. Wide growth rings and low density are associated with juvenile wood, and narrow growth rings with high density are characteristic of mature wood. Therefore, a negative correlation between ring width and density is obvious if both juvenile and mature wood are included in the analysis. As Zobel \& Van Buijtenen (1989) stated, it is the occurrence of juvenile wood (age of growth ring) and not the growth rate by diameter (ring width) that produces lower quality wood.

In general, hard pines tend to show little or no meaningful relationships between wood density and growth rate (Zobel \& Van Buijtenen 1989, Abdel-Gadir et al. 1993) although exceptions have been reported. Gaspar et al. (2009) observed that larger trees tend to present higher values of RD, LWD, LWW, and LWP. They stated that a possible reason for higher or lower wood density in fast growing trees is that growth is due to an increase of LWW or EWW.

Regarding $\mathrm{HI}$, it was found to be less dependent on low EWD values $(r=-0.123)$ and more dependent on high LWD values $(r=0.743)$, which in turn leads to a positive correlation between $\mathrm{HI}$ and mechanical properties $(r=0.267$ and $r=0.297)$. A positive correlation was also observed between $\mathrm{HI}$ and RW ( $r=0.509)$, meaning that higher radial growth causes an increase in $\mathrm{HI}$.

Louzada (2003) also found similar results for the correlation of $\mathrm{HI}$ to EWD (negative) and of LWD to RD (positive), although the latter was very small. However, contrary to the results in this study, the author found a negative correlation of $\mathrm{HI}$ to RW and a positive correlation of $\mathrm{HI}$ to LWP.

\section{Chemical properties of wood}

In general, chemical properties of Scots pine wood were positively correlated in this study (Tab. 6). Among the solvents, highly statistically significant correlations were observed between total and dichloromethane extractive content $(r=0.996)$ and between ethanol and water extractive content $(r=0.550)$.

Klason lignin was highly significantly correlated to its ratio $(\mathrm{H} / \mathrm{G}-\mathrm{r}=0.726)$ and, to a lesser extent, $\mathrm{CP} / \mathrm{cH}(\mathrm{r}=0.290)$, although this was still very significant $(p<0.01)$. The relation of $\mathrm{H} / \mathrm{G}$ and $\mathrm{CP} / \mathrm{cH}$ was not proven to be significant $(r=0.182)$. Highly significant correlations of extractive contents 
obtained by different solvents to Klason lignin $(r=0.259$ to 0.633$)$ and to $H / G(r=$ 0.357 to 0.557 ) were found. Both lignin and its content were slightly more correlated to water than to dichloromethane or ethanol extractive content. Regarding the relation of solvents with $\mathrm{CP} / \mathrm{cH}$, the correlations were statistically less significant, with $r$ values ranging from -0.096 to 0.254 . These results clearly indicate that high amounts of extractives may be related to high lignin and its ratio $(\mathrm{H} / \mathrm{G})$.

It can be observed that chemical properties have, in general, a small relationship with physical and mechanical properties, whose correlations are generally low and not statistically significant (Tab. 6). Gaspar et al. (2011) also found that Klason lignin was weakly correlated with most of the physical and mechanical characteristics of wood in Pinus pinaster.

\section{Radial mechanical properties of wood}

In this study $M O E_{\text {Rad }}$ and $M O R_{\text {Rad }}$ were correlated each other with high significance ( $r=0.779$ - Tab. 6), confirming the results obtained by Gaspar et al. (2011) for Pinus pinaster. MOE is a wood stiffness parameter which is highly and positively correlated with strength, and therefore it can be used to assess wood strength parameters such as MOR (Liu et al. 2007). In fact, the good correlation between strength and elasticity is a consequence of the cellular nature of wood; the mechanism leading to failure along the fibres involves partial cell-wall buckling, which is directly related to cell-wall elasticity. However, the correlation between MOE and MOR also depends on the specimen size, as wood samples of different dimensions may include different proportions of imperfections.

We observed that wood-density components and mechanical properties presented highly significant correlations (Tab. 6 ). These findings are consistent with those previously obtained by Gaspar et al. (2011) for Pinus pinaster, Liu et al. (2007) for Picea mariana, and Steffenrem et al. (2007) for Picea abies. However, only the latter study evaluated wood mechanical traits in the radial direction.

Many researchers have stated that wood density (specific gravity) is one of the major determinants of wood stiffness and strength, where density may explain a large part of the variation in modulus of elasticity in clear wood (Zobel \& Van Buijtenen 1989, Tsoumis 1991). In this study, the correlation of RD to $\mathrm{MOE}_{\text {Rad }}(r=0.482)$ was slightly higher than to $M_{\text {OOd }}(r=0.323-$ Tab. 6). Gaspar et al. (2011) also found a higher correlation of RD to $M E_{\text {Rad }}(r=$ $0.323)$ as compared to $M_{\text {ORad }}(r=0.182)$. On the other hand, Steffenrem et al. (2007), in longitudinal mechanical tests, found that the correlation between density and MOE at the individual tree level was moderate $(r=0.74)$ compared to the very strong correlation between density and MOR $(r=0.91)$. Our results revealed that both mechanical traits had higher correlations with LWD ( $r=0.499-0.443)$ than with EWD ( $r=0.410-0.254$ - Tab. 6). Mechanical traits also presented positive correlations to growth components (EWW, LWW, and RW), although $M O R_{\text {Rad }}$ was found to be more strongly related to ring width than $M E_{\text {Rad }}$ (Tab. 6). Therefore, trees with higher radial growth do not cause a negative outcome in terms of their mechanical performance. Similar results were previously reported by Fernández-Golfin et al. (2004).

\section{Conclusions}

Comparing our results to those reported in the literature, we observed higher values of wood-density components in Pinus sylvestris grown in Portugal as compared with those reported for the same species growing in other European regions, confirming a slight downward trend of wood density with increasing latitude. Some of the observed exceptions may be explained by the older age of trees analyzed in these studies. Regarding ring-width components, the differences were likely due to the effect of age, geographic location or species. Nonetheless, differences among geographic provenances are known more for wood density than for radial growth. Portuguese Pinus sylvestris wood exhibited slightly higher density values than the majority of European conifer species. Compared to Portuguese Pinus pinaster wood, Pinus sylvestris at similar ages presented lower densities, and identical or relatively lower growth.

Portuguese Pinus sylvestris wood has a higher extractive content than other European softwoods, and the amount of total extractives was outside the range attributed to softwoods. Contrastingly, Klason lignin was within the range attributed to softwoods.

Although the available data in the literature is not extensive, we can conclude that Portuguese Pinus sylvestris wood presents high stiffness and strength compared to other softwoods.

Among sampled sites in Portugal, no latitude effects were detected; however, our results revealed a significant effect of altitude on the studied wood-quality traits. Indeed, sites at a lower altitude presented higher density and mechanical properties, and lower amounts of lignin than those at higher altitude.

Regarding the qualitative characteristics of Portuguese Pinus sylvestris, wood from Marão shows good physical and mechanical properties and good growth rates, but presents high heterogeneity within the rings. Therefore, this wood is suitable for uses that require high mechanical resistance, such as lumber and timber beams. On the other hand, wood from Serra da Estrela shows low growth rates and density, but its high within-ring homogeneity makes it suitable for the production of highly valuable wood products such as ply- wood and veneer wood.

Regarding the correlations between wood-quality traits, our results revealed that RD is more strongly correlated with EWD than with LWD. LWP is more dependent on the decrease of EWW than on the increase of LWW. RW presented a slightly higher correlation with EWW $(r=0.947)$ than with LWW ( $r=0.818)$, which is reflected in the negative correlation between RW and LWP ( $r=-0.222)$ as well as RD ( $r=-$ 0.079 ). However, since the latter is not statistically significant, it can be deduced that a higher radial growth (RW) did not negatively affect wood density in Portuguese Scots pine wood.

Within-ring heterogeneity of wood, as expressed by the heterogeneity index $(\mathrm{HI})$ was less dependent on low EWD values ( $r=$ -0.123) but more dependent on high LWD values $(r=0.743)$, which, in turn, induces a positive correlation between $\mathrm{HI}$ and wood mechanical properties $(r=0.267$ and $r=$ 0.297 , respectively for $M O E_{R a d}$ and $M O R_{R a d}$ ). Total extractives were more strongly and positively correlated with dichloromethane content than with ethanol and water content. In general, wood chemical properties showed a low impact on physical and mechanical properties, as revealed by their low and not-significant correlation coefficients.

Both mechanical traits were well correlated with density components (namely LWD) although this was stronger for $M E_{\text {Rad }}$ than for $M O R_{\text {Rad }}$. Mechanical traits also presented positive correlations with growth components (EWW, LWW and RW), which support the assumption that trees with higher radial growth do not present poorer mechanical performance.

Considering the reduction of the forest area of resinous species, Portuguese Pinus sylvestris may represent an important resource for the reforestation of higher altitude areas, which are less favorable for Pinus pinaster, and may become an important resource both for local populations and the Portuguese forestry sector.

\section{Acknowledgements}

This work was partially supported by project PTDC/AGR-CFL/110988/2009 of the Portuguese Foundation for Science and Technology (Fundação para a Ciência e a Tecnologia, FCT) and co-financed by the European Fund of Regional Development (FEDER) under the scope of the COMPETEQREN program. Cláudia Fernandes acknowledges the Portuguese Foundation for Science and Technology (FCT) for her Ph.D. grant (SFRH/BD/98777/2013), co-financed by the Social European Fund (FSE) under the POPH-QREN program. Ana Carvalho and Ana Alves acknowledge FCT Postdoctoral Research Grants SFRH/BPD/ 68932/2010 and SFRH/BPD/72781/2010 COfinanced by the FSE under the POPH-QREN program. Rita Simões acknowledges her BI scholarship (RECI/AGR-TEC/0493/2012). 


\section{Author contributions}

CF: microdensitometric analysis, mechanical tests, interpretation of the results and redaction of the manuscript; MJG: microdensitometric analysis, interpretation of results and text review; JP: sampling of tree cores and microdensitometric analysis; AA: chemical analyses; RS: chemical analyses; JCR: critical revision and interpretation of chemical analyses; MES: sampling of tree cores, microdensitometric analysis and statistical analyses; AC: interpretation of results and text review; JEB: supervision of the project assessing Pinus sylvestris wood (PTDC/AGR-CFL/110988/2009) and critical revision of the manuscript; JLL: sampling of tree cores, microdensitometric analysis, mechanical tests, statistical analyses, critical revision and supervision of the manuscript.

\section{References}

Abdel-Gadir AY, Krahmer RL, McKimmy MD (1993). Relationships between intra-ring variables in mature Douglas-fir trees from provenance plantations. Wood and Fiber Science 25 (2): 182-191.

Aleinikovas M, Grigaliûnas J (2006). Differences of pine (Pinus sylvestris L.) wood physical and mechanical properties from different forest site types in Lithuania. Baltic Forestry 12 (1): 913.

Alves A, Schwanninger M, Pereira H, Rodrigues J (2006). Calibration of NIR to assess lignin composition ( $\mathrm{H} / \mathrm{G}$ ratio) in maritime pine wood using analytical pyrolysis as the reference method. Holzforschung 60 (1): 29-31. - doi: 10.1515/HF.2006.006

Auty D (2006). Non-destructive evaluation of Scots pine (Pinus sylvestris L.) to determine timber quality following conversion to continuous cover forestry systems. Master of Science Dissertation, University of Edinburgh, Scotland, UK, pp. 62.

Auty D, Achim A, Macdonald E, Cameron AD, Gardiner BA (2014). Models for predicting wood density variation in Scots pine. Forestry 87 (3): 449-458. - doi: 10.1093/forestry/cpuoo5 Da Silva Perez D, Guillemain A, Alazard P, Plomion C, Rozenberg $P$, Rodrigues JC, Alves A, Chantre G (2007). Improvement of Pinus pinaster Ait. elite trees selection by combining near infrared spectroscopy and genetic tools. Holzforschung 61 (6): 611-622. - doi: 10.1515/HF.20 07.118

Donaldson LA (1985). Within-and between-tree variation in lignin concentration in the tracheid cell wall of Pinus radiata. New Zealand Journal of Forestry Science 15 (3): 361-369. [online] URL: http://www.scionresearch.com/_data/as sets/pdf_file/0017/30680/NZJFS1531985DONAL DSON361_369.pdf

Fernandes CSR (2006). Avaliação da interacção genótipo $\mathrm{x}$ ambiente nas características de qualidade da madeira de Pinus pinaster [Evaluation of genotype $x$ environment interaction in Pinus pinaster wood quality characteristics]. Master's dissertation in Forest Engineering, Department of Forestry, University of Tras-osMontes and Alto Douro, Vila Real, Portugal, pp. 115. [in Portuguese]
Fernández-Golfin SJ, Díez BMR, Hermoso PE, Conde GM (2004). Mechanical characterization of timber from Spanish provenances of Laricio Pine, according to European standards. Wood Science and Technology 38 (1): 25-34. - doi: 10.1007/s00226-003-0215-3

Fries A, Ericsson T (2006). Estimating genetic parameters for wood density of Scots pine ( $\mathrm{Pi}$ nus sylvestris L.). Silvae Genetica 55 (2): 84-91.

Gaspar MJ, Louzada JL, Silva ME, Aguiar A, Almeida $\mathrm{MH}$ (2008a). Age trends in genetic parameters of wood density components in 46 half-sibling families of Pinus pinaster. Canadian Journal of Forest Research 38 (6): 1470-1477. doi: 10.1139/Xo8-013

Gaspar MJ, Louzada JL, Aguiar A, Almeida $\mathrm{MH}$ (2008b). Genetic correlations between wood quality traits of Pinus pinaster Ait. Annals of Forest Science 65 (7): 703-703. - doi: 10.1051/for est:2008054

Gaspar MJ, Lousada JL, Rodrigues JC, Aguiar A, Almeida $\mathrm{MH}$ (2009). Does selecting for improved growth affect wood quality of Pinus pinaster in Portugal? Forest Ecology and Management 258 (2): 115-121. - doi: 10.1016/j.foreco. 2009.03.046

Gaspar MJ, Alves A, Louzada JL, Morais J, Santos A, Fernandes C, Almeida $\mathrm{MH}$, Rodrigues $\mathrm{JC}$ (2011). Genetic variation of chemical and mechanical traits of maritime pine (Pinus pinaster Aiton). Correlations with wood density components. Annals of Forest Science 68 (2): 255-265. doi: 10.1007/s13595-011-0034-x

Gindl W, Grabner M, Wimmer R (2001). Effects of altitude on tracheid differentiation and lignification of Norway spruce. Canadian Journal of Botany 79 (7): 815-821. - doi: 10.1139/bo1-06o Guller B, Isik K, Cetinay S (2012). Variations in the radial growth and wood density components in relation to cambial age in 30 -Year-Old Pinus brutia Ten. at two test sites. Trees 26 (3): 975986. - doi: 10.1007/s00468-011-0675-2

Hoibo O, Vestol Gl (2010). Modelling the variation in modulus of elasticity and modulus of rupture of Scots pine round timber. Canadian Journal of Forest Research 40 (4): 668-678. doi: 10.1139/X10-021

Karlman L, Mörling T, Martinsson O (2005). Wood density, annual ring width and latewood content in larch and Scots pine. Eurasian Journal of Forest Research 8 (2): 91-96.

Kilpeläinen A, Peltola H, Ryyppö A, Sauvala K, Laitinen K, Kellomäki S (2003). Wood properties of Scots pines (Pinus sylvestris) grown at elevated temperature and carbon dioxide concentration. Tree Physiology 23 (13): 889-897. doi: 10.1093/treephys/23.13.889

Koga S, Zhang SY (2004). Inter-tree and Intratree variations in ring width and wood density components in balsam fir (Abies balsamea). Wood Science and Technology 38 (2): 149-162. doi: 10.1007/s00226-004-0222-z

Koubaa A, Zhang SY, Isabel N, Beaulieu J, Bousquet J (2007). Phenotypic correlations between juvenile-mature wood density and growth in black spruce. Wood and Fiber Science 32 (1): 61-71. [online] URL: http://wfs.swst.org/index.php/ wfs/article/view/1169

Kurz-Besson CB, Lousada JL, Gaspar MJ, Correia IE, David TS, Soares PMM, Cardoso RM, Russo
A, Varino F, Mériaux C, Trigo RM, Gouveia CM (2016). Effects of recent minimum temperature and water deficit increases on Pinus pinaster radial growth and wood density in southern Portugal. Frontiers in Plant Science 7 (595): 131. - doi: 10.3389/fpls.2016.01170

Liu C, Zhang SY, Cloutier A, Rycabel T (2007). Modeling lumber bending stiffness and strength in natural black spruce stands using stand and tree characteristics. Forest Ecology and Management 242 (2-3): 648-655. - doi: 10.1016/j.foreco.2007.01.077

Louzada JL (1991). Variação nas componentes da densidade na madeira de Pinus pinaster Ait. [Variation of the density components in Pinus pinaster Ait. wood]. In: "Technical-Scientific Series, Applied sciences no. 12". UTAD, Vila Real, Portugal, pp. 113. [in Portuguese]

Louzada JL (2000). Variação fenotípica e genética em características estruturais na madeira de Pinus pinaster Ait. O comprimento das fibras e a densidade até aos 80 anos de idade das árvores. Parametros genéticos na evolução juvenil - adulto das componentes da densidade da madeira. [Phenotypic and genetic variation in structural features in Pinus pinaster Ait. wood. The fiber length and density to 80 years of tree's age. Genetic parameters in juvenilemature evolution of wood density components]. In: "Didactic Applied Sciences Series", No. 143, UTAD, Vila Real, Portugal, pp. 293. [in Portuguese]

Louzada JL, Fonseca MA (2002). The heritability of wood density components in Pinus pinaster Ait. and implications for tree breeding. Annals of Forest Science 59 (8): 867-873. - doi: 10.1051/ forest:2002085

Louzada JLPC (2003). Genetic correlations between wood density components in Pinus pinaster Ait. Annals of Forest Science 60 (3): 285294. - doi: 10.1051/forest:2003020

Ohbayashi H, Booker RE, Ball RD, Ridoutt BG (2001). Radial modulus of rupture in radiata pine measured by individual rings. Journal of Wood Science 47 (3): 233-236. - doi: 10.1007/ BF01171227

Peltola H, Gort J, Pulkkinen P, Zubizarreta Gerendiain A, Karppinen J, Ikonen V (2009). Differences in growth and wood density traits in Scots pine (Pinus sylvestris L.) genetic entries grown at different spacing and sites. Silva Fennica 43 (3): 339-354. - doi: 10.14214/sf.192 Pereira H, Graça J, Rodrigues JC (2003). Wood chemistry in relation to quality. In: "Wood quality and its biological basis" (Barnett J, Jeronimidis $G$ eds). John Wiley and Sons. Blackwell, Oxford, UK, pp. 53-86. [online] URL: http:// books.google.com/books?id=NhwSMryGzYoC Pritzkow C, Heinrich I, Grudd H, Helle G (2014). Relationship between wood anatomy, tree-ring widths and wood density of Pinus sylvestris L. and climate at high latitudes in northern Sweden. Dendrochronologia 32 (4): 295-302. - doi: 10.1016/j.dendro.2014.07.003

Rey-Prieto A, Riesco-Muñoz G (2012). Influencia del azulado (mancha azul) en la densidad y estabilidad dimensional de la madera de Pinus sylvestris [Influence of blue stain on density and dimensional stability of Pinus sylvestris timber]. Maderas Ciencia Y Tecnología 14 (1): 115125. [in Portuguese] - doi: 10.4067/S0718-221X 
2012000100010

Riesco-Muñoz G, Soilán Cañas MA, Roíguez Soalleiro R (2008). Physical properties of wood in thinned Scots pines (Pinus sylvestris L.) from plantations in northern Spain. Annals of Forest Science 65 (5): 507-507. - doi: 10.1051/forest:20 08026

Rossi S, Cairo E, Krause C, Deslauriers A (2015). Growth and basic wood properties of black spruce along an alti-latitudinal gradient in Quebec, Canada. Annals of Forest Science 72 (1): 7787. - doi: 10.1007/s13595-014-0399-8

Rozenberg P, Franc A, Bastien C, Cahalan C (2001). Improving models of wood density by including genetic effect: a case study in douglas-fir. Annals of Forest Science 58 (4): 385394. - doi: 10.1051/forest:2001132

Sable I, Grinfelds U, Jansons A, Vikele L, Irbe I, Verovkins A, Treimanis A (2012). Properties of wood and pulp fibers from lodgepole pine (Pinus contorta) as compared to scots pine (Pinus sylvestris). BioResources 7 (2): 1771-1783. - doi: 10.15376/biores.7.2.1771-1783

Schimleck LR, Evans R, Ilic J (2003). Application of near infrared spectroscopy to the extracted wood of a diverse range of species. lawa Journal 24 (4): 429-438. - doi: 10.1163/22941932-900 00347

Schwanninger $M$, Rodrigues JC, Gierlingerc N, Hinterstoisserc B (2011a). Determination of lignin content in Norway spruce wood by Fourier transformed near infrared spectroscopy and partial least squares regression. Part 1. Wavenumber selection and evaluation of the select- ed range. Journal of Near Infrared Spectroscopy 19 (5): 319-329. - doi: 10.1255/jnirs.944 Schwanninger $M$, Rodrigues JC, Gierlingerc N, Hinterstoisserc B (2011b). Determination of lignin content in Norway spruce wood by Fourier transformed near infrared spectroscopy and partial least squares regression. Part 2. Development and evaluation of the final model. Journal of Near Infrared Spectroscopy 19 (5): 331-341. - doi: 10.1255/jnirs.945

Sjöström E, Alén R (2013). Analytical methods in wood chemistry, pulping, and papermaking. Springer Series in Wood Science, Springer-Verlag Berlin Heidelberg, Germany, pp. 318. [online] URL: http://books.google.com/books?id=F $1 \mathrm{kGCAAAQBAJ}$

Steffenrem A, Saranpää P, Lundqvist SO, Skroppa $T$ (2007). Variation in wood properties among five full-sib families of Norway spruce (Picea abies). Annals of Forest Science 64 (8): 799-806. - doi: 10.1051/forest:2007062

Toivanen TJ, Alén R (2006). Variations in the chemical composition within pine (Pinus sylvestris) trunks determined by diffuse reflectance infrared spectroscopy and chemometrics. Cellulose 13 (1): 53-61. - doi: 10.1007/s10570-0059016-1

Tomczak A, Jelonek T, Jakubowski M (2015). Wood density of Scots pine (Pinus sylvestris L.) trees broken by wind. Annals of Warsaw University of Life Sciences - SGGW, Forestry and Wood Technology 76: 144-148.

Tsoumis G (1991). Science and technology of wood-structure, properties, utilization. Van
Nostrand Reinhold, New York, USA, pp. 494. [online] URL: http://www.forstbuch.de/Tsoumi sLeseprobe.pdf

Van Der Maaten-Theunissen M, Boden S, Van Der Maaten E (2013). Wood density variations of Norway spruce (Picea abies L. Karst.) under contrasting climate conditions in southwestern Germany. Annals of Forest Research 56 (1): 91103. [online] URL: http://search.proquest.com/ openview/4ea223724abcec6d40996319462233c o/1

Verkasalo E, Leban JM (2002). MOE and MOR in static bending of small clear specimens of Scots pine, Norway spruce and European fir from Finland and France and their prediction for the comparison of wood quality. Paperi ja Puu 84 (5): 332-340. [online] URL: http://cat.in ist. $\mathrm{fr} /$ ?aModele $=$ afficheN\&cpsidt $=13879839$ Wilhelmsson L, Arlinger J, Spaêngberg K, Lundqvist S, Grahn T, Hedenberg O, Olsson L (2002). Models for predicting wood properties in stems of Picea abies and Pinus sylvestris in Sweden. Scandinavian Journal of Forest Research 17 (4): 330-350. - doi: 10.1080/02827580260138 080

Zhang SY, Jiang ZH (1998). Variability of selected wood characteristics in 40 half-sib families of Black spruce (Picea mariana). Wood Science and Technology 32 (1): 71-82. - doi: $10.1007 / B F O$ 0702561

Zobel BJ, Van Buijtenen JP (1989). Wood variation - its causes and control. Springer Series in Wood Science, Springer-Verlag Berlin Heidelberg, Germany, pp. 363. 